\title{
EVALUATION OF THE CUSTOMER SERVICE QUALITY WITH SERVQUAL METHOD IN THE CHOSEN COMPANY - PART II PERSONNEL PERSPECTIVE
}

\author{
Monika ODLANICKA-POCZOBUTT ${ }^{1 *}$, Arkadiusz SZMAL ${ }^{2}$ \\ ${ }^{1}$ Silesian University of Technology, Faculty of Organization and Management; \\ Monika.Odlanicka-Poczobutt@polsl.pl, ORCID: 0000-0001-7834-1188 \\ ${ }^{2}$ Silesian University of Technology, Faculty of Organization and Management; arkadiusz.szmal@polsl.pl, \\ ORCID: 0000-0001-6395-618X \\ * Correspondence author
}

Purpose: The aim of the paper was to measure the quality of customer service from the perspective of the personnel of the chosen service company using the Servqual method. The scope of the paper concerns the quality of customer service from the perspective of a group of employees hired by the company where the satisfaction research was conducted in part I of the paper.

Design/methodology/approach: The Servqual method was used in the research and its renewed use was governed by the possibility of comparison of the research results while using the same tool. This allows, in the opinion of the authors, for a higher level of significance of references in comparative analysis. The unweighted $\left(\mathrm{SQ}_{\mathrm{n}}\right)$ and weighted $\left(\mathrm{SQ}_{\mathrm{w}}\right)$ servqual indicators were calculated for each of the examined dimensions. They were also interpreted.

Findings: The basis of providing the service that is satisfying to the customer is to recognise the customer expectations and to skilfully transform them into aims and tasks of the service organisation. The effectiveness of realisation of these tasks will depend largely on the competence and motivation of all employees of the service organisation. It is impossible to talk about service quality without analysing the relationships between the service quality and the customer satisfaction.

Research limitations/implications: Extending the research of the customer service quality beyond the perspective of a client by examining the personnel perspective does not exhaust the subject of the research. In the future, a deeper comparative analysis should be made along with monitoring of the changes.

Practical implications: Presented approach finds practical application in the process of identification of the weaknesses of customer service quality and indicates factors of changes which can be used for improving the quality also in small enterprises.

Originality/value The paper confirms the need to use the Servqual method in evaluation of both perspectives, where each of these two assessments may shape the quality of the service understood as general impression of the client which results from comparison of both positive and negative impressions that concern the service company and the service provided.

Keywords: servqual method, customer service, quality.

Category of the paper: Research paper. 


\section{Introduction}

The quality of the customer service is a term closely related to the activities of service companies because it presents a significant reference to the competitive position on the market achieved by the organisation. Enterprises look for various tools that would help to improve their position on the market. They use different tools, including innovation audits (Olko, 2017), looking for endogenous sources of projects that improve the activity (Szmal, 2018), all to deliver to the customer an expected value with optimal cost. Obtaining a satisfying customer service quality is extremely hard because, according to the definition of Valerie A. Zeithaml, A. Parasuraman and Leonard L., the quality of service is shaped by the variance between customer expectations and his/her perception of the service (Zeithaml, Parasuraman, Berry, 1990). It has to be noticed, that there are two kinds of quality of the service - quality of the design and quality of the performance. The first one requires specific skills and activity techniques, mostly from the service organisation. Designing should be subordinated to the wishes of the client, although in practice, the design often suits only the service organisation or, at most, service provider's idea about the customers expectations (Latzko, Saundcrs, 1998). The quality of the service performance is the result of both actions of the service provider and the effect of his/her interaction with the client associated with the ability to meet the client's stated and expected needs (Polski Komitet Normalizacji, 2000).

It is impossible to talk about service quality without analysing the relationships between the service quality and the customer satisfaction (Bitner, Hubbert). However, it should be noted that these are complex relationships, which is highlighted by the broad literature, including (Matusek, 2016), (Sałek, Knop, 2018). In order to capture the essence of the problem, it is necessary to take into account the satisfaction achieved by the client resulting from contact with the service provider and general satisfaction with the services provided. The first one is connected with satisfaction or dissatisfaction of the client perceived in each contact with the service provider, for example during the store visit or while talking with the shop assistant. The second one means satisfaction or dissatisfaction of the client with the services provided by given organisation but as the sum of impressions resulting from all contacts and experiences. Customers service quality acts as a key part in dominating their confirmation of service (Bhattacherjee, 2001b) and generate a higher level of satisfaction and continuance intention. Service quality has often been identified as a driver of cognitive reactions in distinct domains (Shaoa, Lib, Guoc, Zhanga, 2020). Customers who perceive high-quality service are more likely to establish loyalty (Gefen, 2002). If customers perceive gratified service quality, then satisfaction will be generated as an outcome (Rodgers et al., 2005). That perceived service quality can lead an employee to establish proactive commitment, satisfaction, and wellbeing in the organizational context (Sharma et al., 2016). The identified research gap is based on the 
statement that companies do not always use the Servgual method to determine the difference between the perceived and expected level of service quality, but only to determine the current level signaled by the customer. An attempt to fill this gap is to undertake research from two perspectives - the client and the personnel of the examined company. Each of these two assessments may shape the quality of service understood as general impression of the client which results from comparison of both positive and negative impressions that concern the service company and the service provided. The research on customer satisfaction resulting from the offered services was conducted in the paper „Evaluation of the customer service quality with SERVQUAL method in chosen service company - part I customer perspective", but for complementing the image of the service quality, it was proposed to confront the results with perception of the personnel hired by the examined subject. Therefore, the aim of the paper is to measure the quality of customer service from the perspective of the personnel of the chosen service company using the Servqual method. Selection of the tool was governed by the possibility of comparison of the research results while using the same tool. This allows, in the opinion of the authors, for a higher level of significance of references in comparative analysis. The scope of the paper concerns the customer service quality from the perspective of the personnel hired by the company where the satisfaction research was conducted in part I of the paper.

\section{Servqual method - conditions of use}

Analysing the customer service quality, a clear distinction between satisfaction of the client and quality of the service should be made. The level of customer satisfaction is the result of comparing the customer expected quality of service and perceived quality of service. The quality perceived by the client may differ from the quality of performance of the service which is the result of comparing the execution with former requirements. Satisfaction of the customer is subjective because it is a part of the perception optics, but also because the expectations of the clients are extremely diverse (Horodecka, Odlanicka-Poczobutt, 2019). Contact between the customer and the service provider is, on the one hand, the result of a willingness to satisfy the needs of the first one. On the other hand, it is the result of past activity of the service organisation. Therefore, the motives of the contact with particular service provider may constitute the resultant of the intensity of needs experienced by the customer, his/hers financial abilities and flexibility of the service offer reported by the service organisation (Bitner, Hubbert, 1994). The analysis of basic processes constituting realisation of the service might help with capturing all of the most important relationships between service organisation, 
realisation of the service and the assessment made by the customer and the service provider. This study focuses on the employees' point of view.

The quality of service assessment made by the service provider may differ significantly from the assessment of the same service made by the customer. The above statement is confirmed in the research conducted by A. Parasuraman, V.A. Zeithaml, R.R. Berry on the service quality model (Zeithaml, Parasuraman Berry, 1990). The researchers of this team claim that in the perception of service quality there are plenty of deficiencies and variances between the customer and the service provider. The Servqual method is based on the service quality model which is founded on so called five gaps. First gap concerns the difference between the customer expectations about the service and management perception of those expectations in relation to the quality of the offered services. This gap appears when the management of the organisation is unaware of the customer expectations about given service. The second reason may be the incorrectly set weights of the individual features of the services established without their verification by the clients. The second gap is created by the variance between perception of customer expectations by the service organisation and the quality specification of the service. The reason for this variance may lay in the lack of confidence of the management in the possibility of meeting customers expectations and in adequate equipping the service process with tools, devices and relevant procedures. The third gap constitutes the variance between the specification of the service quality and its performance. The reasons for this variance may be found among such factors as: conflicts and imprecise defining of the roles performed by the employees, low qualifications of the personnel, inadequate technology, improper selection of employees working in a team and problems with supervision over the service process. The fourth gap is created by variance between the realisation of the service and the process of outside communication with the customer. Experiences show the variances between the values communicated by advertisement and the seller, and the actual realisation of the service and the fulfilment of promises made. All of the mentioned variances create, as a result the fundamental variance, the so called the fifth gap between the expected service and the service received which decides about the service quality perceived by the customer. Considering the description of the model, it can be stated that the basis of providing the service that is satisfying to the customer is to recognise the customer expectations and to skilfully transform them into aims and tasks of the service organisation. Ultimately, the effectiveness of realisation of such formulated tasks will depend largely on the competence and motivation of all employees of the service organisation. 
The Servqual method was developed by A. Parasurman, L. Berry and V.A. Zeithaml (Berry, Parasuraman, Zeithaml, 1990) and it is used for evaluation of the customer expectations level. The authors of the method emphasised that the service companies should evaluate their usefulness and possibly verify the set of analysed statements by themselves. They defined following uses of this method:

$\checkmark$ determining the average level of discrepancy between the expectations and experiences of the customers,

$\checkmark$ defining the level of quality of enterprise services relating to each of the five basic dimensions,

$\checkmark$ calculating the weighted service quality level considering both gaps of expectations and experiences, and the meaning of specific qualities for the customers,

$\checkmark$ identification of changes in expectations and experiences in time concerning individual qualities and total assessment,

$\checkmark$ comparing analysis results for competing companies,

$\checkmark$ separating market segments, which form different expectations about the service provider, and those who perceive offered services differently,

$\checkmark$ defining the level of provided services in terms of internal marketing, that is the assessment of the quality of the service provided by one organisational unit of the enterprise for the benefit of others.

With multistage scale, it is possible to evaluate the service quality and then indicate the ways for its improvement.

The results of the Servqual method are presented by calculating the weighted and unweighted Servqual result and it is achieved in the course of realisation of the next stages presented in the Figure 1 (Knosala, Hys, 2006). 


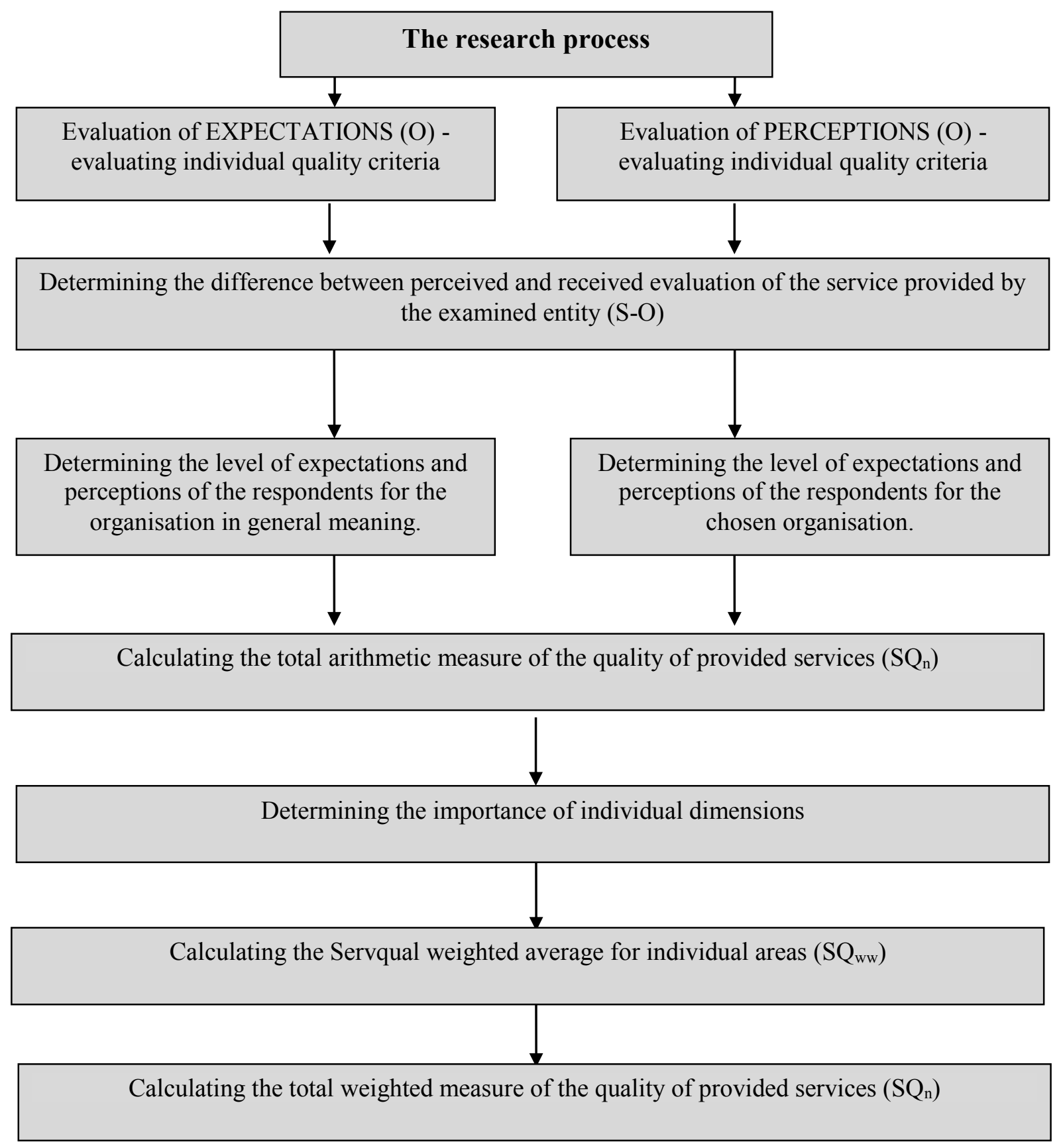

Figure 1. Calculation of the unweighted $\left(\mathrm{SQ}_{\mathrm{n}}\right)$ and weighted $\left(\mathrm{SQ}_{\mathrm{w}}\right)$ Servqual indicators. Source: R. Knosala, K. Hys, Research on service quality in industrial practice, (w): Managing the enterprise, wyd. Polskie Towarzystwo Zarządzania Produkcją, nr 2, 2006, s.18. 


\section{Measurement and evaluation of the quality of service using the Servqual method - personnel perspective}

Evaluation of the quality services made by the employees. The research was conducted under actual conditions in the service company and it provided a basis for evaluation of the services offered by the company. While developing data gathered in the time of research, according to the procedure presented in fig.1. The paper presents perspective of the personnel of the examined entity. Employees in the examined entity evaluated more rigorously the influence of individual criteria on the satisfaction of the client from the quality of service provided by them (Tab. 1). According to the employees, in 9 out of 23 criteria the expectations are equal to the perception or the perception of reality exceeds expectations. However, other criteria, according to the employees, present major deficiencies, as evidenced by arithmetic indicators which were evaluated as worse in relation to the ratings received by the customers. For all the criteria, the ratings given by the employees are between -1 to 0.6 points.

Table 1.

Arithmetic difference of perceptions and expectations regarding the quality of service defined by the employees

\begin{tabular}{|c|c|c|c|c|c|}
\hline \multicolumn{6}{|c|}{ Expectations and perceptions concerning the quality of service - arithmetic measures } \\
\hline & & Quality criteria & $\begin{array}{c}\text { Employees } \\
\text { expectations }\end{array}$ & $\begin{array}{c}\text { Employees } \\
\text { perceptions }\end{array}$ & $\begin{array}{l}\text { Arithmetic } \\
\text { difference }\end{array}$ \\
\hline 1 & tangibles & $\begin{array}{l}\text { Visual attractiveness of the building } \\
\text { and the interior }\end{array}$ & 4.2 & 4.6 & 0.40 \\
\hline 2 & tangibles & $\begin{array}{l}\text { Flexibility in the selection of the } \\
\text { payment method }\end{array}$ & 4.2 & 3.8 & -0.40 \\
\hline 3 & tangibles & Neat appearance of the employees & 4 & 4 & 0.00 \\
\hline 4 & tangibles & $\begin{array}{l}\text { Modern equipment, completeness of } \\
\text { advertising materials }\end{array}$ & 4.4 & 4.4 & 0.00 \\
\hline 5 & tangibles & Wide range of the products & 4.6 & 4.6 & 0.00 \\
\hline 6 & tangibles & Competitive price & 4.6 & 4.4 & -0.20 \\
\hline 7 & reliability & $\begin{array}{l}\text { Keeping the conditions of the realised } \\
\text { sale }\end{array}$ & 4.8 & 4.2 & -0.60 \\
\hline 8 & reliability & Convenience in communication & 3.6 & 4.2 & 0.60 \\
\hline 9 & reliability & Correctness of performed service & 4.8 & 4.4 & -0.40 \\
\hline 10 & reliability & $\begin{array}{l}\text { Reliability and comprehensiveness of } \\
\text { services }\end{array}$ & 4.8 & 4.4 & -0.40 \\
\hline 11 & reliability & Flawless documentation & 4.8 & 4.8 & 0.00 \\
\hline 12 & responsiveness & $\begin{array}{l}\text { Information about the date of the } \\
\text { service }\end{array}$ & 4.8 & 4.6 & -0.20 \\
\hline 13 & responsiveness & Prompt realisation of the service & 4.6 & 4.2 & -0.40 \\
\hline 14 & responsiveness & Professional staff help & 4.2 & 3.8 & -0.40 \\
\hline 15 & responsiveness & $\begin{array}{l}\text { Employee response to the customer } \\
\text { needs }\end{array}$ & 4.6 & 4.2 & -0.40 \\
\hline 16 & assurance & Trust and safety & 4.2 & 4.6 & 0.40 \\
\hline 17 & assurance & Accessibility of the service & 4.4 & 4 & -0.40 \\
\hline 18 & assurance & Opening hours & 4.6 & 4.4 & -0.20 \\
\hline 19 & assurance & $\begin{array}{l}\text { Knowledge and level of personnel } \\
\text { qualifications }\end{array}$ & 4.6 & 3.6 & -1.00 \\
\hline
\end{tabular}


Cont. table 1.

\begin{tabular}{|l|l|l|c|c|c|}
\hline 20 & empathy & Individual approach & 4.4 & 4.8 & 0.40 \\
\hline 21 & empathy & Courtesy and kindness & 5 & 4.8 & -0.20 \\
\hline 22 & empathy & $\begin{array}{l}\text { Loyalty programme for regular } \\
\text { customers }\end{array}$ & 3.8 & 2.8 & -1.00 \\
\hline 23 & empathy & $\begin{array}{l}\text { Understanding the needs of the } \\
\text { customer }\end{array}$ & 4.4 & 4.6 & 0.20 \\
\hline
\end{tabular}

A detailed analysis of the individual quality criteria has shown that, according to the employees, the most positive value is in the „reliability” dimension - „communication convenience". Here, the employees perception is by 0.6 point higher than their expectations about provided service. The criteria in which the employees assessed the quality of their service as too high, rating it 0.4 point, is: „visual attractiveness of the building and the interior”, „trust and safety” and ,individual approach”. Positive value was also assigned to the „understanding of the customers needs" criterion. As an adequate value of their service, which is the one where the expectations equal perceptions, the employees considered: „modern equipment and materials”, „neat appearance of the employees”, ,,a wide range of the products” and „flawless documentation". The rest of identified quality factors were rated negatively, with two criteria being the worst in the ,assurance” dimension - „knowledge and competencies level"”, and in the ,empathy" dimension - „loyalty programme”, with the difference between expectations and perception totalling -1 . This means that the employees relate very critically to their knowledge and experience and to the loyalty programme offered by the store. Poorly rated was also the criterion: „keeping the conditions of the performed sales” (-0.6) in the „reliability” dimension.

In the evaluation of the service quality level, in more complete analysis of the problem, additional mathematical measures were helpful. Determining the importance of particular dimensions, the respondents had to assign the weight to them (Table 2). Obtained results, from the most significant dimension, arrange as follow:

- responsibility,

- assurance,

- reliability,

- tangibles,

- empathy.

Table 2.

The importance of the quality dimensions in the opinion of the employees

\begin{tabular}{|c|c|c|c|c|c|}
\hline & \multicolumn{5}{|c|}{ Quality dimensions } \\
\cline { 2 - 6 } & tangibles & reliability & responsibility & assurance & empathy \\
\hline $\begin{array}{c}\text { The importance } \\
\text { of dimension }\end{array}$ & 18 & 20 & 23 & 22 & 17 \\
\hline
\end{tabular}


On the basis of the obtained results concerning the importance of individual quality dimensions, the following measures were calculated, necessary for evaluation of the service level offered by the examined enterprise in the opinion of its employees (Tab. 3). Similarly to the arithmetic difference, 14 out of 23 criteria, by assigning weights to them, also obtained negative values. However, there was a slight change in revaluation of the worst rated criteria. Still, even after assigning weights to the criteria, the most points were given the „communication convenience” criterion (12), and the least to the „knowledge and qualification level" (-22).

Table 3.

Arithmetic difference, weighted difference and importance of quality dimensions in the opinion of the employees

\begin{tabular}{|c|c|c|c|c|c|}
\hline \multicolumn{6}{|c|}{$\begin{array}{l}\text { Expectations and perceptions concerning the service quality - arithmetic difference, weighted difference } \\
\text { and importance of the quality dimensions in the opinion of the customers }\end{array}$} \\
\hline \multicolumn{2}{|r|}{ Dimension } & Quality criteria & Arithmetic & Weight of & Weighted \\
\hline 1 & tangibles & $\begin{array}{l}\text { Visual attractiveness of the building } \\
\text { and the interior }\end{array}$ & 0.40 & \multirow{6}{*}{18} & -7.2 \\
\hline 2 & tangibles & $\begin{array}{l}\text { Flexibility in the selection of the } \\
\text { payment method }\end{array}$ & -0.40 & & -7.2 \\
\hline 3 & tangibles & Neat appearance of the employees & 0.00 & & 0.0 \\
\hline 4 & tangibles & $\begin{array}{l}\text { Modern equipment, completeness of } \\
\text { advertising materials }\end{array}$ & 0.00 & & 0.0 \\
\hline 5 & tangibles & Wide range of the products & 0.00 & & 0.0 \\
\hline 6 & tangibles & Competitive price & -0.20 & & -3.6 \\
\hline 7 & reliability & $\begin{array}{l}\text { Keeping the conditions of the realised } \\
\text { sale }\end{array}$ & -0.60 & \multirow{5}{*}{20} & -12.0 \\
\hline 8 & reliability & Convenience in communication & 0.60 & & 12.0 \\
\hline 9 & reliability & Correctness of performed service & -0.40 & & -8.0 \\
\hline 10 & reliability & $\begin{array}{l}\text { Reliability and comprehensiveness of } \\
\text { services, }\end{array}$ & -0.40 & & -8.0 \\
\hline 11 & reliability & Flawless documentation & 0.00 & & 0.0 \\
\hline 12 & responsiveness & $\begin{array}{l}\text { Information about the date of the } \\
\text { service }\end{array}$ & -0.20 & \multirow{4}{*}{23} & -4.6 \\
\hline 13 & responsiveness & Prompt realisation of the service & -0.40 & & -9.2 \\
\hline 14 & responsiveness & Professional staff help & -0.40 & & -9.2 \\
\hline 15 & responsiveness & $\begin{array}{l}\text { Employee response to the customer } \\
\text { needs }\end{array}$ & -0.40 & & -9.2 \\
\hline 16 & assurance & Trust and safety & 0.40 & \multirow{4}{*}{22} & 8.8 \\
\hline 17 & assurance & Accessibility of the service & -0.40 & & -8.8 \\
\hline 18 & assurance & Opening hours & -0.20 & & -4.4 \\
\hline 19 & assurance & $\begin{array}{l}\text { Knowledge and level of personnel } \\
\text { qualifications }\end{array}$ & -1.00 & & -22.0 \\
\hline 20 & empathy & Individual approach & 0.40 & \multirow{4}{*}{17} & 6.8 \\
\hline 21 & empathy & Courtesy and kindness & -0.20 & & -3.4 \\
\hline 22 & empathy & $\begin{array}{l}\text { Loyalty programme for regular } \\
\text { customers }\end{array}$ & -1.00 & & -17.0 \\
\hline 23 & empathy & $\begin{array}{l}\text { Understanding the needs of the } \\
\text { customer }\end{array}$ & 0.20 & & 3.4 \\
\hline
\end{tabular}


Ultimately, by comparing the quality assessments (tab.3), the unweighted ( $\mathrm{SQ}_{\mathrm{n} 1 . . \mathrm{SQ}} \mathrm{n}$ ) and weighted ( $\left.\mathrm{SQ}_{\mathrm{w} 1} . . \mathrm{SQ} \mathrm{w}_{\mathrm{w} 5}\right)$ servqual indicator was determined for individual dimensions (tab. 4). The biggest disproportions are in the third dimension - meaning the responsibility for the service. That is the quality dimension (criteria which create it) that, according to the employees, should be analysed as first by the owner of the business.

\section{Table 4.}

Unweighted and weighted servqual indicators for each of the quality dimensions in the opinion of the employees

\begin{tabular}{|l|c|c|}
\hline \multicolumn{2}{|c|}{ Unweighted SQ (SQnw) and weighted SQ (SQw) for each of the consumers dimensions } \\
\hline Dimension & SQ nw & SQ w \\
\hline Dimension 1: tangibles & -0.03 & -0.6 \\
\hline Dimension 2: reliability & $-0,16$ & $-3,2$ \\
\hline Dimension 3: responsiveness & $-0,35$ & $-8,05$ \\
\hline Dimension 4: assurance & $-0,3$ & $-6,6$ \\
\hline Dimension 5: empathy & $-0,15$ & $-2,55$ \\
\hline & $-0,20$ & $-4,20$ \\
\hline
\end{tabular}

\section{Conclusion}

Employees by their assessment of the quality of services offered by them indicated that priority should be given to the training expanding their knowledge and qualifications. This would allow for reliable and fast information transfer about the products offered by the store. As the result, the personnel would gain more confidence and easiness in conversation with the client while creating a pleasant sale atmosphere. Similarly to the clients, the employees pointed out the problems with the loyalty programme for customers. They assessed that it is very sparing and is the reason for the customers to use to services of a competitor.

In the businesses with very similar product offer available in alike prices, the only way to compete for the clients is by introducing new services and continuously improving their activities. Keeping a loyal customer, by caring for his satisfaction, generates much less costs than constant acquiring of the new clients. The purchase in a given store is primarily influenced by its location, opening hours and prices, but it is the customer service that distinguishes given store among the competition. That is why it is important to create positive relations from the very first meeting and to continue the conversation that is adjusted to the level of the customer. A satisfied customer is more willing to talk about the assets of the offer therefore contributing to acquiring new customers.

The research made the employees aware of the need to constantly improve the quality of services. The logistic support plays an important part in their everyday activity. Individual approach, good knowledge of the preferences of the client and frequent contact leads to increasing the effectiveness of the employees' work. An important element of the personnel 
activities is reliable, fast and complete informing about the products. Such created satisfaction of the client becomes the main factor influencing the loyalty of the customers. Highly specialised suppliers aim for the customer service to be formed on the high quality, implementing the policy of the service based on the mission and key values.

The basis of providing the service that is satisfying to the customer is to recognise the customer expectations and to skilfully transform them into the aims and tasks of the service organisation. The effectiveness of realisation of these tasks will depend largely on the competence and motivation of all employees of the service organisation. By making a slight mistake in terms of meeting customer expectations, a given service organisation may lose customers to a competitor who better meets these expectations. That is why the assessment of the customer service from the perspective of the personnel was analysed in this paper.

\section{References}

1. Bhattacherjee, A. (2001). Understanding information systems continuance: an expectationconfirmation model. MIS Q., 351-370. https://doi.org/10.2307/3250921.

2. Bitner, M.J., Hubbert, A.R. (1994). Encounter satisfaction versus overall satisfaction versus quality. In: R.T. Rust, R.L. O1iver, Service Quality. New Directions in theory and practice. SAGE Publications, p. 76.

3. Gefen, D. (2002). Customer loyalty in e-commerce. J. Assoc. Inf. Syst. 3, 2. https://doi.org/ 10.17705/1 jais.00022.

4. Horodecka, A.M., Odlanicka-Poczobutt, M. (2019). Measurement of quality services in courts - the SERVQUAL method. Scientific Papers of Silesian University of Technology, Organization and Management Series, No. 138, p. 93.

5. Kisperska-Moroń, D., Płaczek, E., Piniecki, R. (2003). Zarządzanie logistyczne w firmach ustugowych. Katowice: Wydawnictwo Akademii Ekonomicznej, pp. 123-124.

6. Knosala, R., Hys, K. (2006). Badania jakości usług w praktyce przemysłowej. Zarzadzanie przedsiębiorstwem, nr 2. Polskie Towarzystwo Zarządzania Produkcją, p. 18.

7. Latzko, W.J., Saunders, D.M. (1998). Cztery dni z dr Demingiem - nowoczesna teoria zarządzania. Warszawa: WNT, p. 187.

8. Matusek, M., (2016) Wymiary złożoności usług (logistycznych). Zesz. Nauk. PŚl., Org. Zarz., z. 99, pp. 287-296.

9. Olko, S. (2017). Audyt innowacyjności przedsiębiorstwa-zakres merytoryczny wybranych podejść praktycznych. Przegląd Organizacji, nr 7, pp. 38-44.

10. Polski Komitet Normalizacyjny, PN-9000:2000. 
11. Rodgers, W., Negash, S., Suk, K. (2005). The moderating effect of on-line experience on the antecedents and consequences of on-line satisfaction. Psychol. Mark., 22, 313-331. https://doi.org/10.1002/mar.20061.

12. Sałek, R., Knop, L. (2019). Concepts of a production company's logistics strategy development in aspect of supply chain management. 8th Carpathian Logistics Congress. CLC 2018. Logistics, Distribution, Transport \& Management, Prague, Tanger, pp. 771-778.

13. Shaoa, Z., Lib, X., Guoc, Y, Zhanga, L. (2020). Influence of service quality in sharing economy: Understanding customers' continuance intention of bicycle sharing. Electronic Commerce Research and Applications, Vol. 40, 100944.

14. Sharma, P., Kong, T.T.C., Kingshott, R.P.J. (2016). Internal service quality as a driver of employee satisfaction, commitment and performance: Exploring the focal role of employee well-being. J. Serv. Manag., 27, 773-797. https://doi.org/10.1108/JOSM10-2015-0294.

15. Szmal, A. (2018). Projekt racjonalizatorski jako endogeniczne źródło innowacji. Zesz. Nauk. PŚl., Org. Zarz., z. 120, pp. 183-194.

16. Wolniak, R., Skotnicta-Zasadzień, B. (2009). Wykorzystanie metody Servqual do badania jakości usług w administracji samorządowej. Gliwice: Wydawnictwo Politechniki Śląskiej, pp. 38-43.

17. Zeithaml, V.A., Parasuraman, A., Berry, L.L. (1990). Delivering Quality Service. Balancing customer perceptions and expectations. The Free Press, p. 20, 46. 